\title{
Systolic blood pressure and blood volume in preterm infants
}

\author{
K Bauer, O Linderkamp, H T Versmold
}

\begin{abstract}
Blood volume and systolic blood pressure (SBP) were measured in 43 preterm infants. Mean (SD) blood volume was 83 (19) $\mathrm{ml} / \mathrm{kg}$ (range 48-119) and SBP 50 (9) mm Hg (range 34-69), showing a significant overall relationship. Blood volume in infants with SBP $>60 \mathrm{~mm} \mathrm{Hg}$ (110 (6) $\mathrm{ml} / \mathrm{kg}$ ) was significantly higher than in infants with SBP 40-60 mm $\mathrm{Hg}$ (78 (16) $\mathrm{ml} / \mathrm{kg}$ ) and in infants with SBP $<40 \mathrm{~mm}$ $\mathrm{Hg}$ (75 (10) $\mathrm{ml} / \mathrm{kg})$. In conclusion, SBP is of limited value in detecting hypovolaemia in very low birthweight infants.

(Arch Dis Child 1993; 69: 521-522)
\end{abstract}

Arterial hypotension is an important risk factor in the aetiology of cerebral lesions in very low birthweight (VLBW) infants. ${ }^{1}$ Several studies have shown that the arterial blood pressure in preterm infants increases in response to blood volume expansion, ${ }^{12}$ thereby suggesting that hypovolaemia is a frequent cause of hypotension in these infants. Robinson et al observed that a blood transfusion increased the systolic blood pressure (SBP) in low birthweight infants only if before transfusion SBP was less than $35 \mathrm{~mm} \mathrm{Hg}^{3}$

A clear relationship between blood volume and arterial blood pressure has not been established for preterm infants. Previous studies on the relationship between blood volume and arterial blood pressure included preterm infants with a wide range of birth weights ${ }^{2-4}$ so that blood pressure may have been determined by birth weight ${ }^{5}$ rather than by blood volume.

The present investigation was designed to study blood volume and SBP in preterm infants within the first two days of birth.

Division of

Department of

Paediatrics, University

of Heidelberg, Im

Neuenheimer Feld 150,

D-69120 Heidelberg,

Germany

Otwin Linderkamp

Department of

Paediatrics, Hospital

Center Steglitz, Free

University of Berlin,

Bniversity of Berlin, Germany

Karl Bauer

Hans T Versmold

Correspondence to: Dr Linderkamp.

Accepted 23 July 1993

\section{Patients and methods}

Forty three premature infants treated in the neonatal intensive care unit of the Division of Neonatology, University of Munich, were studied with the approval of the department of Paediatrics Human Subjects Research Committee and with informed consent of one or both parents. Gestational age ranged from 27-31 weeks and birth weight from 800 $1499 \mathrm{~g}$. All infants had a birth weight appropriate for gestational age (10th-90th centile). The infants received an infusion of $10 \%$ glucose in water (3.0-3.5 ml/kg/hour). Twenty seven infants received mechanical ventilation through an endotracheal tube. At the time of investigation, arterial $\mathrm{pH}$ was $7 \cdot 30-7 \cdot 43$, arterial carbon dioxide tension $4 \cdot 7-6 \cdot 7 \mathrm{kPa}$, and arterial oxygen tension $7 \cdot 3-10 \cdot 0 \mathrm{kPa}$. The infants did not receive transfusions, bicarbonate, sedatives, or vasoactive drugs before they were examined.

In infants with an umbilical artery catheter $(n=14)$, SBP was measured with a pressure transducer (Hewlett Packard, Geneva, Switzerland). In the other infants, SBP was measured using oscillometry technique (Dinamap, Criticon, Tampa, FL, USA. Packed cell volume (PCV) was determined by a micro method using a correction factor of 0.98 for trapped plasma. Plasma volume was measured by Evans blue dilution using a double wavelength method. ${ }^{6}$ Blood volume was calculated from the plasma volume (in $\mathrm{ml}$ ) and the PCV (in $1 / 1$ ):

Blood volume $=$ plasma volume $/[1-(\mathrm{PCV} \times 0.91)]$ where the factor 0.91 is the body/venous PCV ratio. ${ }^{6}$

Analysis of variance (one way with Scheffe test) was performed to test for differences of blood volume among preterm infants with SBP $<40 \mathrm{~mm} \mathrm{Hg}$ (10th centile), 40-60 $\mathrm{mm} \mathrm{Hg}$, and $>60 \mathrm{~mm} \mathrm{Hg}$ (90th centile). Regression analysis was used to determine overall correlation between SBP and blood volume.

\section{Results}

The mean (SD) blood volume of the 43 infants was $83(19) \mathrm{ml} / \mathrm{kg}$ and the SBP $50(9) \mathrm{mm} \mathrm{Hg}$. In the 27 ventilated infants, blood volume was 79 (20) $\mathrm{ml} / \mathrm{kg}$ and SBP 49 (8) $\mathrm{mm} \mathrm{Hg}$. The figure shows that SBP did not increase with increasing blood volume as long as the blood volume did not exceed $100 \mathrm{ml} / \mathrm{kg}$. However,

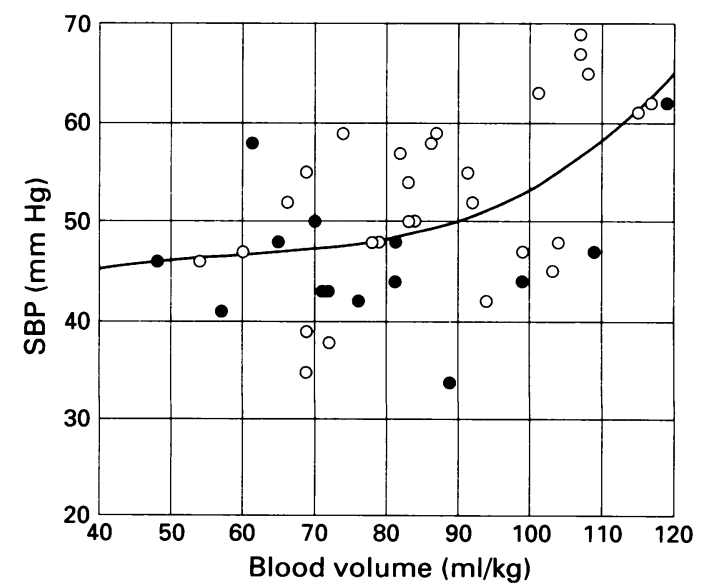

Relationship between SBP and blood volume in the preterm infants studied. $A$ third order polynomial function was computed for fitting the data; the relationship was significant $(r=0.54 ; p<0 \cdot 001)$. SBP was measured by oscillometry (open circles) or via an umbilical artery catheter (closed circles). 
the seven infants with $\mathrm{SBP}>60 \mathrm{~mm} \mathrm{Hg}$ (>90th centile) had a higher mean blood volume (110 (6) $\mathrm{ml} / \mathrm{kg}$ ) than the infants with SBP of $40-60 \mathrm{~mm} \mathrm{Hg}(78(16) \mathrm{ml} / \mathrm{kg})$ and the infants with SBP $<40 \mathrm{~mm} \mathrm{Hg}$ (75 (10) $\mathrm{ml} / \mathrm{kg}$ ).

\section{Discussion}

The results indicate that SBP in VLBW infants does not change markedly with increasing blood volume over wide range of blood volume values, whereas raised SBP $(>60 \mathrm{~mm} \mathrm{Hg})$ indicates hypervolaemia (figure). Barr et al found no relationship between blood pressure and blood volume in preterm infants even at high blood volume. ${ }^{2}$ This may be explained by the wide range of birth weights $(750-3300 \mathrm{~g}$ ) in the study of Barr et $a l^{2}$ whereas we studied only infants with birth weight of 800-1499 g.

As SBP increased only at blood volume $>100 \mathrm{ml} / \mathrm{kg}$ (figure), our study suggests that a low blood pressure is not a reliable indicator of hypovolaemia in VLBW infants. This indicates that many preterm infants respond to low blood volume by sufficient vasoconstriction to maintain SBP.
We conclude that hypotension in VLBW infants of 2-48 hours of age does not necessarily signal low blood volume, but may also indicate relative blood volume deficiency (that is increased vascular capacity) or cardiac failure.

This study was supported by a grant from the Deutsche Forschungsgemeinschaft ( $\mathrm{Li} \mathrm{291/4).}$

1 Bada HS, Korones SB, Perry EH, et al. Mean arterial blood pressure changes in premature infants and those at risk for intraventricular hemorrhage. $f$ Pediatr 1990; 117: for intrave

2 Barr PA, Bayley PE, Sumners J, Cassady G. Relation between arterial blood pressure and blood volume and effect of infused albumin in sick preterm infants. Pediatrics 1977; 60: 282-9.

3 Robinson RO, Fujimura M, Howat P, Salisbury DM. Effect of blood transfusion in low birthweight infants. Arch Dis Child 1977; 62: 248-52.

4 Linderkamp O, Strohhacker I, Versmold HT, Klose H, Riegel KP, Betke K. Peripheral circulation in the newborn: interaction of peripheral blood flow, blood pressure, blood volume, and blood viscosity. Eur $\mathcal{f}$ Pediatr 1978; 129: 73-81.

5 Versmold HT, Kitterman JA, Phibbs RH, Gregory GA Tooley WH. Aortic blood pressure during the first 12 hours of life in infants with birth weight 610 to 4220 grams. Pediatrics 1981; 67: 607-13.

6 Linderkamp O, Mader T, Butenandt O, Riegel KP. Plasma volume estimation in severely ill infants and children using a simplified Evans blue method. Eur $\mathcal{F}$ Pediatr 1977; 125: 135-41. 